\author{
Safety Considerations for Fabricating \\ Lithium Battery Packs \\ James J. Ciesla \\ Electrochem Industries, Clarence, New York
}

\begin{abstract}
Lithium cell safety has been a major issue with both manufacturers and end users since first discussed by Brooks (1) and Warburton (2) at the 1974 Power Sources Symposium. Most manufacturers have taken great strides to develop the safest cells possible while still maintaining performance characteristics. The combining of lithium cells for higher voltages, currents, and capacities requires the fabricator of lithium battery packs to be knowledgeable about the specific electrochemical system being used.

The following will refer to relatively high rate, spirally wound (large surface area) sulfur oxychloride cell systems, such as Li/Thionyl or Sulfuryl Chloride. Prior to the start of a design of a battery pack, a review of the characterization studies for the cells should be conducted. The approach for fabricating a battery pack might vary with cell size.
\end{abstract}

\title{
INTRODUCTIOE
}

All lithium cell manufacturers recommend limits on the use of a cell for any given application. These limits may or may not have an incorporated safety factor. For the purpose of building a battery pack from any of the cells that are available, it would be prudent to treat the advertised specifications as a working limit. Battery pack designers must look at the same abusive conditions as cell designers. These are high-rate discharge, shorting, forced discharge, charging, overheating, and mechanical abuse. Although single cells may react well under one or more of the above abusive conditions, a battery pack, when subjected to the same conditions, may present a hazard or not function as expected. As an example, a cell discharged at a maximum continuous current of three amperes will dissipate heat at a rate that will keep the cell below its maximum rated temperature. Should a battery be discharged at the same $3 \mathrm{~A}$ rate, in a cluster, the internal pack temperature may easily exceed the cell temperature limits. Although the battery pack's intended use may require low current drains at room temperature, the designer must account for all conditions that might compromise battery safety. 
The following steps are a precursor to a functional and safe battery design. Knowledge of the performance, storage, environmental, and abuse requirements for the system into which a pack is going will enable the battery pack designer to foresee safety problems about which the system designer may be unaware.

\section{APPLICATION DESCRIPTION}

A detailed description of the intended use of a battery will give direction for the successful design of the product. The description may help the designer to move in a more positive manner with respect to the overall safety of the pack design and its fabrication. This method of approach will lead to specific questions that are germane to the application.

\section{GENERAL PERFORMANCE REQUIREMENTS}

These will include minimum voltage, maximum voltage, average current, peak current, capacity, minimum temperature, maximum temperature, duty cycles (intermittent or continuous), motion, and orientation.

\section{SPECIFIC REQUIREMENTS}

These include available space, weight, method of attachment and termination.

\section{DISCUSSIOI}

With all of the above data taken into account, a preliminary battery pack design should now be analyzed for safety. All precautions should be taken to keep the cells in the pack from cresting the cell's upper temperature limits.

The battery construction should take into account all possible adverse conditions. Some of these scenarios could be venting, shorting, charging, cell reversal, mechanical abuse and overheating. Should a single cell in a battery pack vent, there should be an unrestricted escape path leading away from the cell's venting mechanism - preferably to the pack's exterior or to an absorbent material.

The major protective method for an external short circuit of the pack is through use of fuses. These fuses can be placed internal to the pack or externally in the power supply wires. A replaceable, fast acting fuse will offer the greatest protection and minimize capacity loss. If the fuse is external, it may be replaced after the short is cleared. By far, the highest occurrence of short circuiting in a battery pack is during the installation of a connector. Slow blow fuses are sometimes 
used when surge or pulse currents are required. Fuse values should be set at the lowest levels possible for the application.

To protect against cell or series string charging from external power supplies or parallel strings, blocking diodes are used in each series string. Diode placement is usually within a battery pack, but can be external, if standard series packs are assembled into a larger power source. Cells of the same age and history should be used to assemble power sources.

A partially discharged cell in series with a number of fresh cells has been shown to eventually overheat due to forced discharge by the fresher cells. Reversed biased diodes on each cell in a series string may offer some protection against cell voltage reversal. In this case, other factors such as diode leakage current and cell or series string capacity loss must be considered.

Mechanical abuse may happen after the battery pack has been installed in a system or while it is being handled during installation or removal. Each application will dictate the amount of safeguarding necessary during battery design and building.

Overheating cells or battery packs will lead to venting or, in more extreme cases, cell rupture. The following will deal with internally generated heat due to cell discharge.

A current limiting resistor is often used in series with a battery pack, and will, depending on the application, restrict the current level of the battery to a safe level. In most cases a thermally activated device will be utilized to keep the pack from exceeding the safe temperature limit of the cells. Items such as thermal cutoffs (TCO) and polymeric positive temperature coefficent (PTC) resistors are in common use. The PTC can be either temperature or current activated. It will handle transients or brief current overloads. Trip time may typically run from about 0.1 to 1000 seconds dependent upon the degree of overload. Once tripped, the PTC resistor remains in a high resistance state, so long as the source voltage is maintained.

A TCO is primarily a thermal trip device but can be activated due to high current self-heating. A thermal pellet inside the TCO melts when overheated. TCO's are not able to be reset and must be replaced after being tripped. The outer case of the TCO is electrically live, and consideration must be given to this fact when it is being installed in a battery pack. Selection of a TCO to correspond to the maximum recommended temperature of a cell may not offer the protection desired. TCO's are often covered with insulation due to the "electrically live" case. 
With this in mind, a series of tests were conducted to characterize the temperature lag between the cell wall and the TCO temperature.

\section{TEST PROCEDURE}

A slip fit copper slug with a pencil heater connected to a Variac was inserted into a double D case. Two layers of PVC shrink-wrap were placed on the exterior of the DD case along with two TCO cases. The internal mechanisms of the $\mathrm{TCO}^{\prime} \mathrm{s}$ were removed (Figure 1). Thermocouples were placed at the inside and outside of the metal can walls, on each layer of shrink-wrap, and in each TCO case. Thermal grease was used between the copper slug and the cell case and in each TCO case to facilitate heat transfer. One TCO case had been covered with one layer of shrinktube. This was done to account for the fact that the TCO case is electrically live in normal use. TCO attachment to the cell was accomplished with cyanoacrylate adhesive. The test setup was covered with a $17 \mathrm{~cm} \mathrm{H} \times 17 \mathrm{~cm} \mathrm{~W} \times 12 \mathrm{~cm} \mathrm{~L}$ box to simulate a dead air environment. All test runs were begun at $24^{\circ} \mathrm{C}$. The cell wall temperatures were used to determine the heating rate. Although the heating rate for each test run was not linear, an average heating rate was calculated over the total run time.

$$
\begin{aligned}
44^{\circ} \mathrm{C} / \mathrm{minute} & \text { (Figure 2) } \\
23^{\circ} \mathrm{C} / \mathrm{minute} & \text { (Figure 3) } \\
10^{\circ} \mathrm{C} / \mathrm{minute} & \text { (Figure } 4) \\
10^{\circ} \mathrm{C} / \mathrm{minute} & \text { (Figure 5) }
\end{aligned}
$$

In all cases there is an expected lag between the cell wall and TCO temperatures. The thermal cutoff with no shrinktube showed a marked improvement in response to the cell wall temperature, over the thermal cutoff with shrinktube. A closer look at the data for the $1 \%$ minute test run, and the temperature of the non-insulated TCO at the $73^{\circ} \mathrm{C}$ mark, showed a corresponding cell wall temperature of $82^{\circ} \mathrm{C}$. A $68^{\circ} \mathrm{C}$ TCO temperature had a corresponding $76^{\circ} \mathrm{C}$ cell wall temperature. These nine and eight degree temperature lags correspond to fourteen and thirteen degrees respectively during the $10^{\circ} \mathrm{C} /$ minute heating rate.

An increase in heat transfer between the cell and TCO was facilitated by mixing copper metal dust with the cyanoacrylate adhesive. The differential for the $10^{\circ} \mathrm{C} / \mathrm{minute}$ run was now eight degrees. This is a forty-five percent increase in heat transfer for a non-insulated TCO. The increase over the insulated TCO was sixty percent.

Table 1 presents a comparison between an insulated TCO and the cell wall temperature at the various heating rates. The non-insulated TCO with conductive adhesive for the $10^{\circ} \mathrm{C} / \mathrm{minute}$ rate is at the far right. Table 2 presents the temperature lag for the same conditions. 
One other non-insulated TCO was attached to the cell wall with the same conductive adhesive. This was a functional TCO. A multimeter was attached to the leads of the TCO and monitored for loss of continuity during a $10^{\circ} \mathrm{C} /$ minute run. The trip temperature for this TCO was $72^{\circ} \mathrm{C}$ $\left(+0,-4^{\circ} \mathrm{C}\right)$. This TCO tripped 4.4 minutes after the cell wall

temperature hit $72^{\circ} \mathrm{C}$. The thermocouple in the non-insulated TCo case with conductive adhesive indicated a temperature of $100^{\circ} \mathrm{C}$. The cell

wall temperature at that time was $111^{\circ} \mathrm{C}$.

\section{TEST SUMHARY}

Conductive adhesive will greatly improve the heat transfer for thermal cutoffs. Appreciable temperature lag can result if a thermal cutoff is insulated prior to installation. Careful consideration must be given to the trip temperature of a TCO if it is to act as a protection device in the event of cell self-heating.

\section{COMCLUSION}

The design and construction of a lithium battery pack must be accomplished methodically if it is to function in a safe manner. Devices which are added to a cluster of cells have their own distinctive characteristics and these should be understood if they are to be relied upon as a safety item.

The reaction time of a thermal cutoff will be different than the above test if it is in a cluster of cells, in a colder or hotter environment, has air movement by it, or is from a different manufacturer. A battery pack becomes a system in itself that must be looked at from every perspective. Overall safety depends on it! 


\section{REFERENCES}

1. Brooks, E.S., Proc. $26^{\text {th }}$ Power Sources Conf., p. 31, 1974

2. Warburton, D.L., Proc. $26^{\text {th }}$ Power Sources Conf., p. 34, 1974 
Table 1. CELL WALL AND TCO TEMPERATURE COMPARISON

\begin{tabular}{|c|c|c|c|c|c|}
\hline \multicolumn{5}{|c|}{ CELL WALL VS IRSULATED TCO TEITPEATURE } & \multirow{2}{*}{$\begin{array}{c}\text { Conductive } \\
\text { Adhesive }\end{array}$} \\
\hline \multirow[t]{2}{*}{ Ce11 Wall ( $\left.{ }^{\circ} \mathrm{C}\right)$} & \multicolumn{4}{|c|}{ TCO $\left({ }^{\circ} \mathrm{C}\right)$} & \\
\hline & $\begin{array}{c}\text { He } \\
1\end{array}$ & $\begin{array}{r}\text { Rat } \\
10\end{array}$ & $\begin{array}{l}\text { Min) } \\
23\end{array}$ & 44 & 10 \\
\hline 55 & 47 & 45 & 40 & 31 & 49 \\
\hline 75 & 63 & 55 & 50 & 43 & 67 \\
\hline 85 & 72 & 60 & 55 & 49 & 76 \\
\hline 95 & 80 & 70 & 64 & 55 & 85 \\
\hline 105 & 87 & 79 & 69 & 60 & 95 \\
\hline 115 & - & 85 & 79 & - & 103 \\
\hline
\end{tabular}


Table 2. TCO TEMPERATURE LAG

\begin{tabular}{|c|c|c|c|c|c|}
\hline \multicolumn{5}{|c|}{ CELL VALL VS INSULATED TCO (TEIPERATURE LAG) } & \multirow{2}{*}{$\begin{array}{l}\text { Conductive } \\
\text { Adhesive }\end{array}$} \\
\hline \multirow[t]{3}{*}{ Cell Wall $\left({ }^{\circ} \mathrm{C}\right)$} & \multicolumn{4}{|c|}{$\operatorname{TCO}\left({ }^{\circ} \mathrm{C}\right)$} & \\
\hline & \multicolumn{4}{|c|}{ Heating Rate ( $\left.{ }^{\circ} \mathrm{C} / \mathrm{Min}\right)$} & \\
\hline & 1 & 10 & 23 & 44 & 10 \\
\hline 55 & 8 & 10 & 15 & 24 & 6 \\
\hline 75 & 12 & 20 & 25 & 32 & 8 \\
\hline 85 & 13 & 25 & 30 & 36 & 9 \\
\hline 95 & 15 & 25 & 31 & 40 & 10 \\
\hline 105 & 18 & 26 & 36 & 45 & 10 \\
\hline 115 & - & 30 & 36 & - & 12 \\
\hline
\end{tabular}




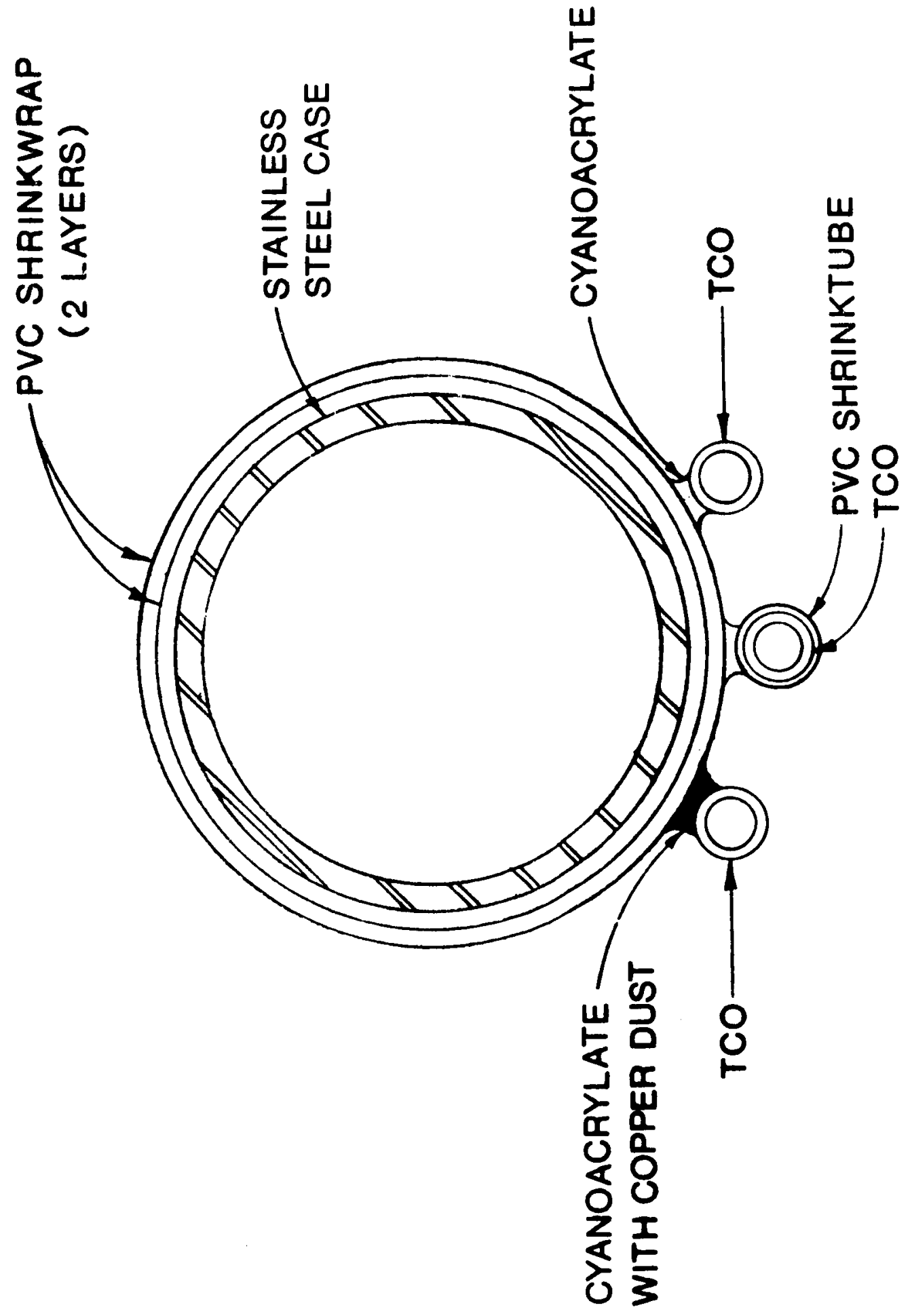

它 


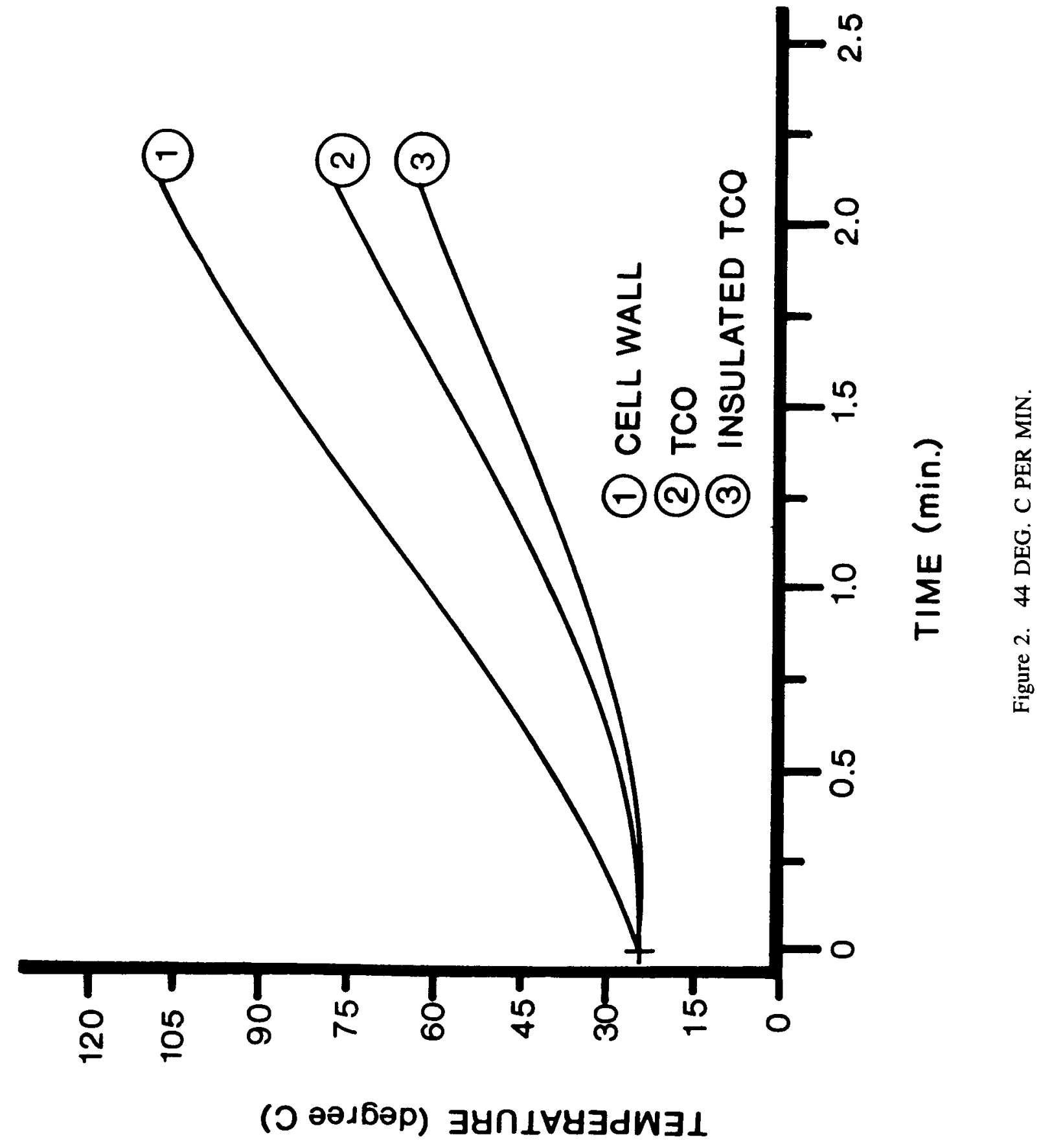




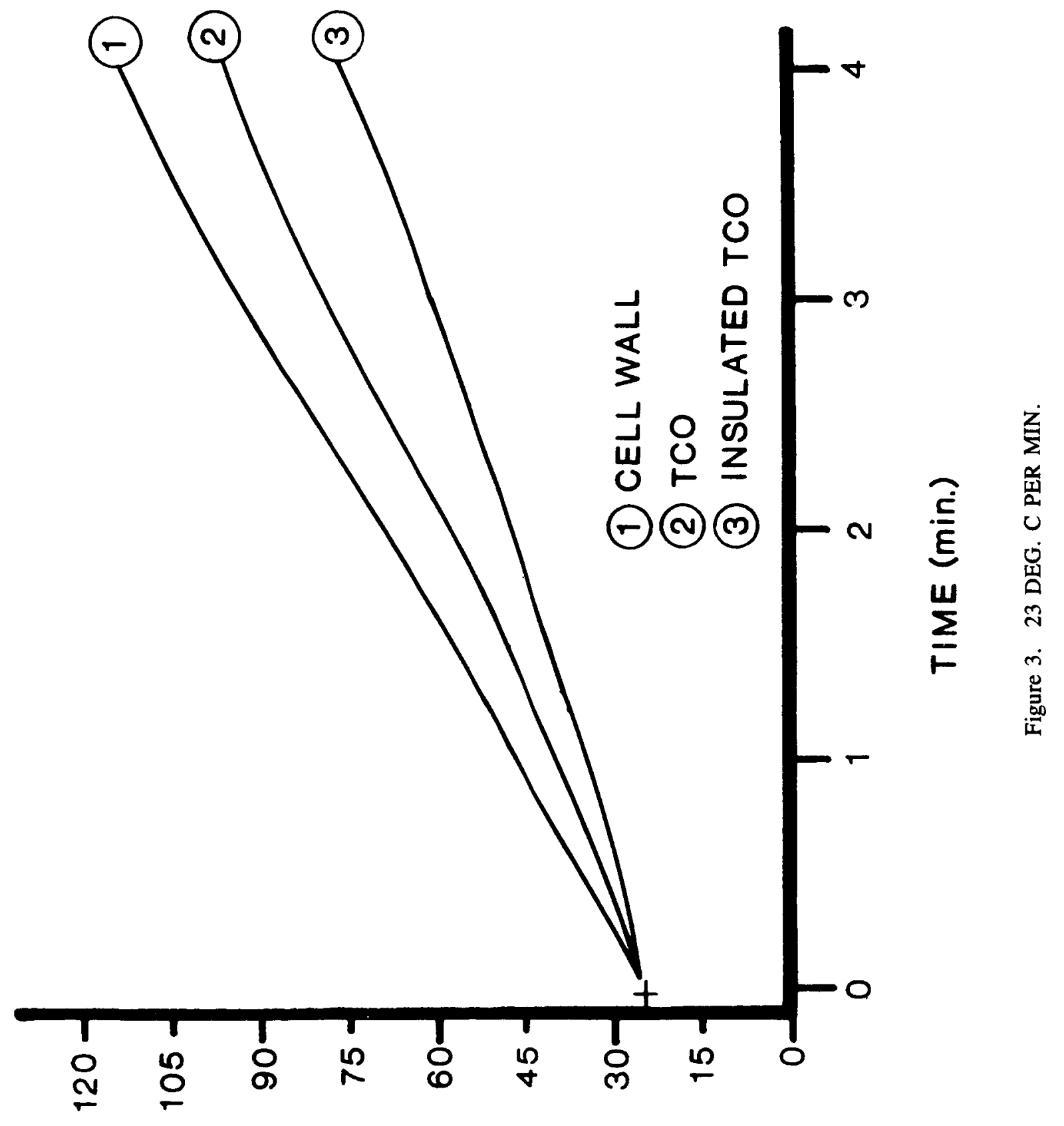

(כo) $\exists \forall n \perp \forall y \exists d W \exists \perp$ 


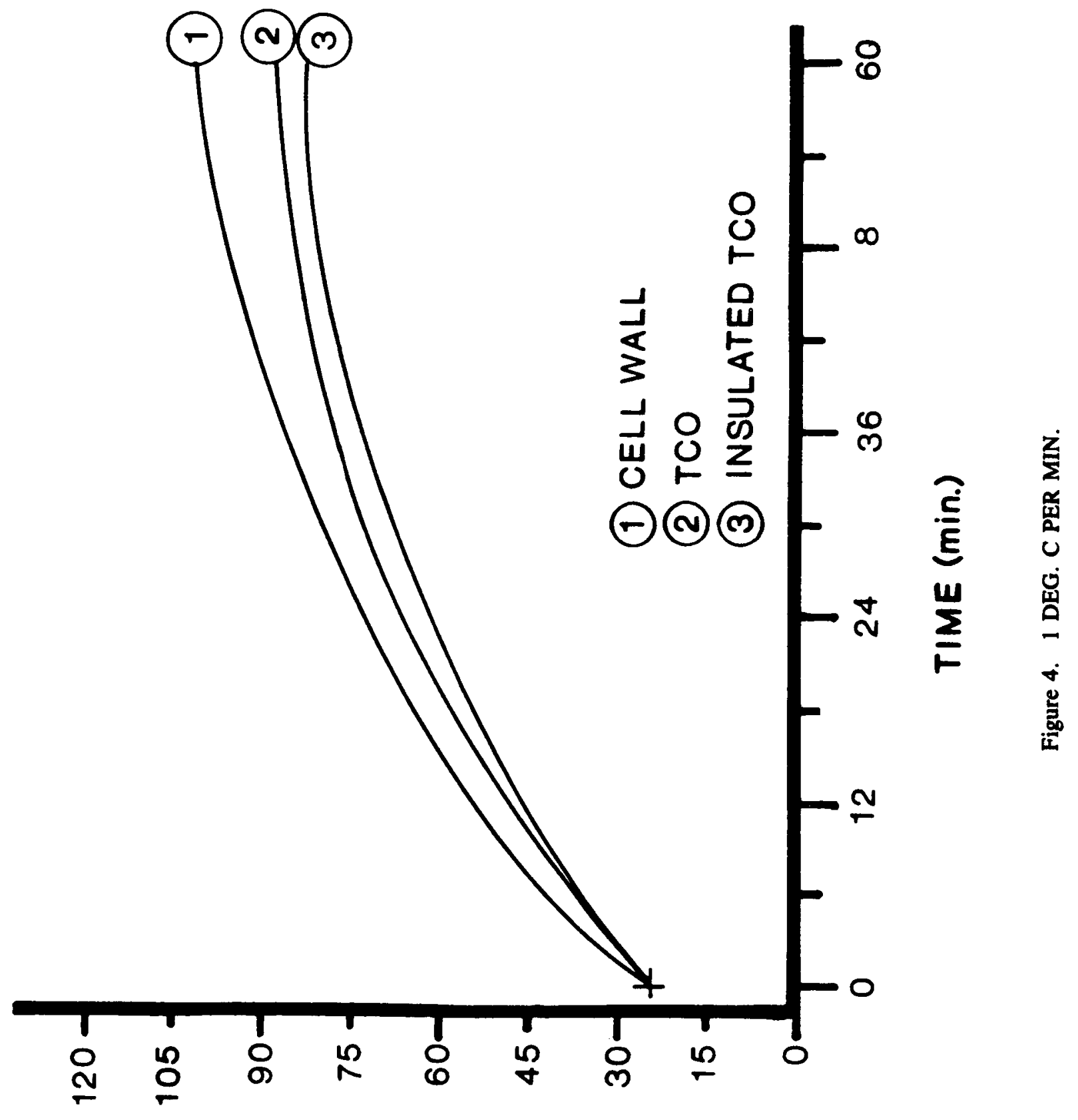

(כo) $\exists y \cap 1 \forall y \exists d W \exists \perp$ 


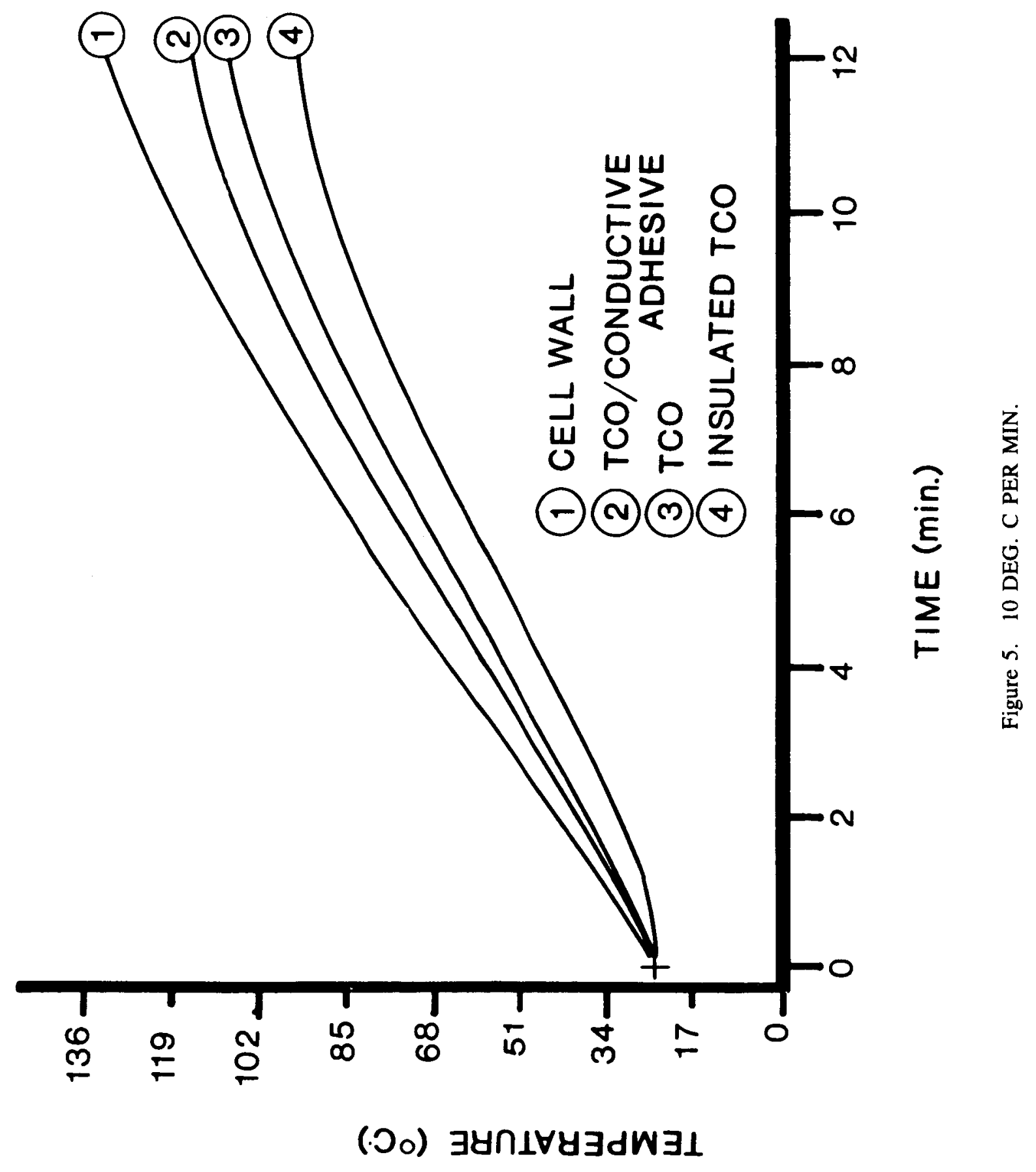

